\title{
Characterization of the resistance class 1 integrons in Staphylococcus aureus isolates from milk of lactating dairy cattle in Northwestern China
}

\author{
Longping $\mathrm{Li}^{1,2,3}$ and Xin Zhao ${ }^{1,4^{*}}$
}

\begin{abstract}
Background: Integrons are mobile DNA elements and they have an important role in acquisition and dissemination of antimicrobial resistance genes. However, there are limited data available on integrons of Staphylococcus aureus (S. aureus) from bovine mastitis, especially from Chinese dairy cows. To address this knowledge gap, bovine mastitis-inducing $S$. aureus isolates were investigated for the presence of integrons as well as characterization of gene cassettes. Integrons were detected using PCR reactions and then further characterized by a restriction fragment-length polymorphism analysis and amplicon sequencing.

Results: All 121 S. aureus isolates carried the class 1 integrase gene int/1, with no int/2 and int/3 genes detected. One hundred and three isolates were positive for the presence of 12 resistance genes, either alone or in combination with other gene cassettes. These resistance genes encoded resistance to trimethoprim (dhfrV, dfrA,$d f r A 12)$, aminoglycosides ( aadA1, aadA5, aadA4, aadA24, aacA4, aadA2, aadB), chloramphenicol ( $\mathrm{cm} / \mathrm{A6}$ ) and quaternary ammonium compound $(\mathrm{qaCH})$ and were organized into 11 different gene cassettes arrangements (A-K). The gene cassette arrays dfrA1-aadA1 ( $\mathrm{D}, 44.6 \%)$, aadA2 (K, 31.4\%), dfrA12-orfX2-aadA2 (G, 27.3\%) and aadA1 (A, 25.6\%) were most prevalent. Furthermore, 74 isolates contained combinations of 2 to 4 gene cassette arrays. Finally, all of the integron/cassettes-positive isolates were resistant to aminoglycoside antibiotics.
\end{abstract}

Conclusions: This is the first study on the integrons and gene cassette arrays in S. aureus isolates from milk of mastitic cows from Northwestern China and provide the evidence for class 1 integron as possible antibiotic resistance determinants on dairy farms.

Keywords: Class 1 integron, Gene cassettes, Antibiotic resistance, Bovine milk, Staphylococcus aureus

\section{Background}

Staphylococcus aureus (S. aureus) induced bovine mastitis causes heavy losses for the dairy industry worldwide. In addition, acquisition and spread of antibiotic resistance among staphylococcal strains is a major concern in treatment of staphylococcal infections in humans and animals. The evolution of multidrug resistance is relatively fast due to horizontal or lateral gene transfer,

\footnotetext{
* Correspondence: zhaoxin@nwsuaf.edu.cn

${ }^{1}$ College of Animal Science and Technology, Northwest A\&F University, YangLing, Shaanxi, People's Republic of China

${ }^{4}$ Department of Animal Science, McGill University, 21,111 Lakeshore, Ste.

Anne de Bellevue, Quebec H9X 3V9, Canada

Full list of author information is available at the end of the article
}

which is influenced by a wide range of mobile genetic elements [1]. In particular, integrons comprise a substantial proportion of these elements and are often found in plasmids and/or transposons that enhance spread of resistance genes [2].

Integrons are mobile DNA elements that are composed of three DNA segments, including a $5^{\prime}$ conserved segment $\left(5^{\prime} \mathrm{CS}\right)$, an internal variable region with one or more resistance gene cassettes of different lengths and sequences, and a $3^{\prime}$ conserved segment ( $\left.3^{\prime} \mathrm{CS}\right)$. The 5'CS encodes a recombinase (integrase) which allows for sitespecific insertion of resistance-gene cassettes between two highly conserved adjacent nucleotide sequences 
(5'CS and $3^{\prime} \mathrm{CS}$ ) and a promoter that ensures expression of the integrated gene cassettes. The 3'CS contains a quaternary ammonium compound resistance gene $q a c \Delta E-1$, the sulfonamide resistance gene sul1 and an open reading frame of an unknown function [3]. At present, at last 5 classes of mobile integrons have been distinguished by their highly conserved class-specific integrase genes [3] and gene cassettes are widely disseminated in diverse bacteria [2]. Mobile integrons have been a major driver in the spread of antibiotic resistance and ongoing use of antibiotics has swelled their numbers in recent years [2].

The role of class 1 integrons is well known in the spread of antibiotic resistance genes in gram-negative bacteria [4, 5]. A previous study has also shown that gram-positive bacteria were a major reservoir of class 1 antibiotic resistance integrons in poultry litter [6]. Furthermore, nosocomial infection caused by resistance class 1 integron-carrying S. aureus [7] or methicillinresistant $S$. aureus $[8,9]$ were also reported in Southern China. However, investigation of integrons in bovine milk-associated $S$. aureus is still lacking. Therefore, the aims of this work were (i) to determine the class 1 integron-associated genes in S. aureus isolates obtained from dairy farms in Shaanxi province in Northwestern China and (ii) to amplify and characterize their gene cassette contents and antibiotic resistance gene cassette arrays by sequencing of $S$. aureus isolates.

\section{Methods}

\section{Bacterial strains and susceptibility testing}

Milk samples were collected from 4 dairy farms in three cities (BaoJi, XiAn and XianYang) in the Shaanxi Province. These 4 farms had 24 to 68 lactating cows and samples were collected between September 2011 and October 2012. Milk samples were taken from cows with clinical mastitis. Cows were selected by veterinarians based on clinical mastitis which was manifested with decreased milk production, color change of the milk and inflammation of udders. Milk samples were collected after cleaning the teats, discarding a few streams of milk and scrubbing the teat ends with cotton balls moistened with $70 \%$ alcohol. In all, $121 \mathrm{~S}$. aureus isolates were isolated from 214 individual quarter milk samples which were obtained from 161 cows. Conventional antimicrobials including penicillin, kanamycin, gentamicin and erythromycin were used alone or combination for the treatment of clinical mastitis on these farms.

One hundred and twenty one $S$. aureus isolates from bovine milk were identified by biochemical methods, including a test for catalase, a tube coagulase test and anaerobic fermentation of mannitol. The identification was also confirmed by PCR amplification and sequencing of species-specific region of the gene encoding $16 \mathrm{~S}$ rRNA and by amplification of thermonuclease gene $(n u c)$ [10].

Antibiotic susceptibility testing was performed by the standard disc diffusion method on Mueller-Hinton agar (Oxoid, UK) plates according to Clinical and Laboratory Standards Institute (CLSI) guidelines [11, 12]. The antimicrobial agents (Oxoid, England) tested were (the disk concentration of the antibiotics indicated in parentheses): penicillin $\mathrm{G}(10 \mathrm{U})$, ampicillin $(10 \mu \mathrm{g})$, gentamicin $(10 \mu \mathrm{g})$, kanamycin $(30 \mu \mathrm{g})$, tetracycline $(30 \mu \mathrm{g})$, erythromycin $(15 \mu \mathrm{g})$, clindamycin $(2 \mu \mathrm{g})$ and chloramphenicol $(30 \mu \mathrm{g})$ as in our previous studies [10, 13]. In addition, the susceptibility of antibiotics trimethoprim/ sulfamethoxazole (SXT, 1.25/23.75, $25 \mu \mathrm{g}$ ) was conducted in the present study. S. aureus ATCC 25923 was used as a quality control. Results of susceptibility testing were recorded according to the CLSI $[11,12]$ guidelines following incubation at $35^{\circ} \mathrm{C}$ for $18 \mathrm{~h}$.

\section{Detection of three classes of integrases, gene cassettes and $3^{\prime}$ conserved region}

Plasmid and chromosome DNA of bacterial isolates were extracted using a commercial DNAout kit (Tiandz Inc., Beijing, China) as described previously [13]. The presence of class 1,2, and 3 integrons was analyzed in all isolates in the present study. The primers were used to detect the intI1 [6], intI2 [6] and intI3 [14] genes as in previous studies using a touchdown program: $94{ }^{\circ} \mathrm{C}$ for $5 \mathrm{~min}$, ten touchdown cycles of $94{ }^{\circ} \mathrm{C}$ for $30 \mathrm{~s}, 68{ }^{\circ} \mathrm{C}$ for $30 \mathrm{~s}$ (decreasing by $1{ }^{\circ} \mathrm{C} /$ cycle) and $72{ }^{\circ} \mathrm{C}$ for $1 \mathrm{~min}$, followed by 30 cycles of $30 \mathrm{~s}$ at $94{ }^{\circ} \mathrm{C}, 30 \mathrm{~s}$ at $58^{\circ} \mathrm{C}$ and $1 \mathrm{~min}$ at $72{ }^{\circ} \mathrm{C}$, with a final extension for $10 \mathrm{~min}$ at $72^{\circ}$ $\mathrm{C}\left(\mathrm{C}_{1000^{\mathrm{rm}}}\right.$ Thermal Cycler, BIO-RAD, Beijing, China). The PCR products of the class 1 integrase gene (intI1) were randomly selected for sequencing to ensure specificity and accuracy. Amplicons of intI1 were purified with a PCR purification kit (TransGen Biotech, Beijing, China), ligated into the $p E A S Y^{\odot}-\mathrm{T} 5$ Zero Cloning Vector (TransGen Biotech, Beijing, China), and then sequenced at Nanjing GenScript Ltd. (Nanjing, China). Sequence comparisons were performed using the BLAST program (http://www.ncbi.nlm.nih.gov/BLAST/). In addition, $2 \times$ TransTaq ${ }^{\circ}-\mathrm{T}$ PCR SuperMix (+dye) (TransGen Biotech, Beijing, China) was employed to amplify the variable region (gene cassettes) between the intI1 gene and the 3'CS of class 1 integron using primers sets 5'CS and 3'CS as described previously [14] and following a threestep program [15] with minor modifications: 1 min of denaturation at $94{ }^{\circ} \mathrm{C}, 1 \mathrm{~min}$ of annealing at $52{ }^{\circ} \mathrm{C}$ and 2 min of extension at $72{ }^{\circ} \mathrm{C}$ for a total of 35 cycles; $5 \mathrm{~s}$ were added to the extension time at each cycle. Furthermore, two genes strongly associated with Class 1 integrons, the non-mobile cassettes conferring resistance to 
sulfadiazine, sul 1 , and to quaternary ammonium compounds, $q a c \Delta E$-1, were also detected [6].

\section{Restriction fragment length polymorphism (RFLP) and DNA sequencing analysis of cassette regions}

To determine whether each cassette gene PCR amplicon with the same size had the same content, cassette PCR products were digested with AluI or RsaI (New England Biolabs, Beijing, China). The PCR products with the same RFLP pattern were considered to contain same gene cassettes. To analyze the sequences of the gene cassettes, 1 or 2 cassette amplicons representative of each restriction profile were excised, purified and ligated into $p E A S Y^{\circ}-\mathrm{T} 5$ Zero Cloning Vector (TransGen Biotech, Beijing, China). The ligation mixture was transformed into Trans-T1 Phage Resistant Chemically Competent Cell (TransGen Biotech, Beijing, China) and recombinants were selected on Luria agar containing ampicillin $(100 \mathrm{mg} / \mathrm{L})$. Recombinant plasmid DNA was purified by standard methods and subjected to sequencing at Nanjing GenScript Ltd. (Nanjing, China). The nucleotide sequences were analyzed and compared with available sequences in GenBank using the BLAST program by the National Center for Biotechnology Information (http://www.ncbi.nlm.nih.gov/blast/).

\section{Results}

Antimicrobial resistance profiles

High levels of resistance to antibiotics had been found in the bovine milk-associated $S$. aureus isolates, including to penicillin G (97/121, 80.2\%), ampicillin (97/121, 80.2\%), kanamycin $(83 / 121,68.6 \%)$, gentamicin $(82 / 121,67.8 \%)$, tetracycline (52/121, 43\%), erythromycin $(40 / 121,33.1 \%$; 38 isolates exhibited the inducible macrolide-lincosamide-streptogramin resistance phenotype and 2 isolates expressed the constitutive macrolide-lincosamide-streptogramin resistance phenotype and chloramphenicol $(36 / 121,29.8 \%)$ in our previous reports using the same isolates $[10,13]$. Furthermore, $32.2 \%$ (39/121) of the isolates were resistant to SXT in the present study (Table 1). In addition, $89.3 \%$ (108/121) of the isolates were resistant to at least one antimicrobial, $47.1 \%(57 / 121)$ to three or more different classes of antimicrobials.

\section{Detection of class 1, 2 and 3 integrons}

One hundred and twenty-one bovine milk associated $S$. aureus isolates were assayed by PCR amplification for the three classes of integrase genes. All isolates yielded a

Table 1 Antimicrobial resistance phenotypes ${ }^{a}$ and genotypes

\begin{tabular}{|c|c|c|c|c|c|c|c|c|}
\hline \multirow[t]{2}{*}{$\begin{array}{l}\text { Antimicrobial } \\
\text { subclass }\end{array}$} & \multirow[t]{2}{*}{$\begin{array}{l}\text { Antimicrobial } \\
\text { agent }\end{array}$} & \multicolumn{2}{|l|}{ Phenotypes } & \multicolumn{5}{|c|}{$\begin{array}{l}\text { Genotypes } \\
\text { (No. of isolates contained different resistance gene } \\
\text { cassettes or type) }\end{array}$} \\
\hline & & $\begin{array}{l}\text { No. of resistant } \\
\text { isolates (\%) }\end{array}$ & $\begin{array}{l}\text { No. of sensitive } \\
\text { isolates }\end{array}$ & $\begin{array}{l}\text { aadA1, aadA2, aadA4, } \\
\text { aadA5, aadA24, aacA4 } \\
\text { or aadB }\end{array}$ & $\begin{array}{l}\text { dhfrV, dfrAl } \\
\text { or dfrA12 }\end{array}$ & $\mathrm{qaCH}$ & $\mathrm{cm} / \mathrm{A} 6$ & $\begin{array}{l}\text { type } \mathrm{H} \text { integron } \\
\text { only }\end{array}$ \\
\hline \multirow[t]{4}{*}{ Aminoglycosides } & \multirow[t]{2}{*}{ gentamicin } & $82(67.8)$ & - & 61 & I & / & / & 21 \\
\hline & & - & 39 & 24 & / & / & / & 6 \\
\hline & \multirow[t]{2}{*}{ kanamycin } & 83(68.6) & - & 62 & / & / & / & 21 \\
\hline & & - & 38 & 25 & / & / & / & 6 \\
\hline \multirow{2}{*}{$\begin{array}{l}\text { Folate pathway } \\
\text { inhibitors }\end{array}$} & \multirow{2}{*}{$\begin{array}{l}\text { trimethoprim/ } \\
\text { sulfamethoxazole } \\
\text { (SXT) }\end{array}$} & $39(32.2)$ & - & / & 28 & / & / & 5 \\
\hline & & - & 82 & I & 46 & / & / & 20 \\
\hline \multirow[t]{2}{*}{ Phenicols } & \multirow[t]{2}{*}{ chloramphenicol } & $36(29.8)$ & - & / & / & / & 5 & 4 \\
\hline & & - & 85 & / & / & / & 13 & 23 \\
\hline \multirow[t]{4}{*}{ Pencillins } & \multirow[t]{2}{*}{ Penicillin G } & $97(80.2)$ & / & / & / & / & / & 25 \\
\hline & & - & 24 & / & / & / & / & 3 \\
\hline & \multirow[t]{2}{*}{ ampicillin } & $97(80.2)$ & / & / & / & / & / & 25 \\
\hline & & - & 24 & / & / & / & / & 3 \\
\hline \multirow[t]{2}{*}{ Macrolides } & \multirow[t]{2}{*}{ erythromycin } & $40(33.1)$ & / & / & / & / & / & 11 \\
\hline & & - & 81 & / & / & / & / & 16 \\
\hline \multirow[t]{2}{*}{ Lincosamides } & \multirow[t]{2}{*}{ clindamycin } & $2(1.7)$ & / & / & / & / & / & 1 \\
\hline & & - & 119 & / & / & / & / & 26 \\
\hline \multirow[t]{2}{*}{ Tetracyclines } & \multirow[t]{2}{*}{ tetracyclin } & $52(43)$ & / & / & / & / & / & 11 \\
\hline & & - & 69 & / & / & / & / & 12 \\
\hline
\end{tabular}

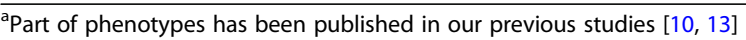


$280 \mathrm{bp}$ PCR products, none of the isolates yielded 233 and $717 \mathrm{bp}$ products. These suggested that all tested isolates had the class 1 integrase gene (intI1), with no class 2 and 3 integrase genes detected. Furthermore, all isolates were positive for the presence of qac $\Delta E-11$ and sul1 genes, which are also the markers for class 1 integrons.

\section{Characterization of antibiotic resistance gene cassettes in} class 1 integrons

Antibiotic resistance genes were detected using a CS-based PCR assay in which the primers flanked the variable region of the integron. Among 121 intI1 gene positive S. aureus, $85.1 \%(103 / 121)$ of isolates carried different gene cassettes.

Sequence analyses of PCR products representing each of the PCR-RFLP profiles identified a single gene cassette in the amplicons with sizes of $781 \mathrm{bp}$ (A), $1048 \mathrm{bp}$ (B), $874 \mathrm{bp}$ (I) and $1009 \mathrm{bp}(\mathrm{K})$. Two gene cassettes present in tandem were detected in the $1360 \mathrm{bp}(\mathrm{C})$, 1586 bp (D), 1608 bp (E) and 1648 bp (F) amplicons, and three gene cassettes were present in the $1913 \mathrm{bp}(\mathrm{G})$ and $3149 \mathrm{bp}(\mathrm{J})$ amplicons. The $153 \mathrm{bp}(\mathrm{H})$ amplicon was found to be a class 1 integron variable region without any gene cassette but contained partial sequences of $5^{\prime}$ and $3^{\prime}$ conserved segments of integrons. The resistance gene cassettes of those isolates are shown in Table 2, while the schematic representation of the inserted gene cassettes is shown in Fig. 1. In the present study, we found 2 open reading frames with unknown functions ( $\operatorname{orf} X 1$ and $\operatorname{orf} X 2$ ) and one $153 \mathrm{bp}$ amplicon $(\mathrm{H})$. The remaining genes encoded resistance to trimethoprim ( $d h f r V, d f r A 1$ and $d f r A 12)$, aminoglycosides (adA1, aadA5, aadA4, aadA24, aacA4, aadA2 and $a a d B)$, chloramphenicol (cmlA6) and quaternary ammonium compound ( $q a c H)$ (Table 2). Furthermore, 11 distinct kinds of gene cassette arrays (A-K) were identified (Table 2, Fig. 1). Of them, the gene cassette arrays dfrA1-aadA1 (D, 44.6\%), aadA2 (K, 31.4\%), dfrA12hypothetical protein-aadA2 (G, 27.3\%) and aadA1 (A, $25.6 \%)$ were found to be most prevalent. In addition, among 103 gene cassettes-positive isolates, 74 isolates contained 2 to 4 gene cassettes combinations, 26 isolates with $\mathrm{H}$ only and 3 isolates with $\mathrm{G}$ only (Table 3 ). The most frequent combinations were $\mathrm{D}+\mathrm{K}+\mathrm{I}+\mathrm{H}$ (22 isolates) and $\mathrm{J}+\mathrm{G}+\mathrm{D}$ (18 isolates). To our knowledge, those gene cassette arrays have not been reported in bovine milk-associated $S$. aureus isolates previously, although all of these gene cassette arrays exist in other types of bacteria.

\section{The association between integron/cassettes and antimicrobial resistance}

All of the integron/cassettes-positive isolates were resistant to aminoglycoside antibiotics. However, no gene
Table 2 Different gene cassette amplicon and numbers of isolates containing the gene cassette among 121 bovine milk associated S. aureus

\begin{tabular}{|c|c|c|c|}
\hline Cassette types & $\begin{array}{l}\text { Amplicon } \\
\text { size (bp) }\end{array}$ & $\begin{array}{l}\text { Resistance } \\
\text { gene }(\mathrm{s})\end{array}$ & $\begin{array}{l}\text { No. of isolates } \\
(\%)\end{array}$ \\
\hline A & 781 & $\operatorname{aad} A 1$ & 31 (25.6) \\
\hline B & 1048 & aadA5 & $3(2.5)$ \\
\hline \multirow[t]{2}{*}{ C } & 1360 & dhfrV & $4(3.3)$ \\
\hline & & $\operatorname{aad} A 4$ & \\
\hline \multirow[t]{2}{*}{ D } & 1586 & dfral & $54(44.6)$ \\
\hline & & aadAl & \\
\hline \multirow[t]{2}{*}{ E } & 1608 & $\begin{array}{l}\text { hypothetical } \\
\text { protein (orf } x_{1} \text { ) }\end{array}$ & $3(2.5)$ \\
\hline & & $\operatorname{aadA24}$ & \\
\hline \multirow[t]{2}{*}{$\mathrm{F}$} & 1648 & aacA4 & $4(3.3)$ \\
\hline & & aadAl & \\
\hline \multirow[t]{3}{*}{ G } & 1913 & dfrA12 & $33(27.3)$ \\
\hline & & $\begin{array}{l}\text { hypothetical } \\
\text { protein (orfX2) }\end{array}$ & \\
\hline & & $\operatorname{aadA2}$ & \\
\hline $\mathrm{H}$ & 153 & - & 71 (58.7) \\
\hline I & 874 & qacH & $2(1.65)$ \\
\hline \multirow[t]{3}{*}{ J } & 3149 & $a a d B$ & $18(14.9)$ \\
\hline & & aadAl & \\
\hline & & $\mathrm{Cm} / \mathrm{A} 6$ & \\
\hline K & 1009 & $\operatorname{aadA2}$ & $38(31.4)$ \\
\hline
\end{tabular}

cassette conferring resistance to erythromycin, clindamycin, tetracycline, penicillin and ampicillin was identified in the present study, thus the gene cassette arrays observed in our study did not account for those antimicrobial resistance phenotypes.

Among 39 SXT resistant and 36 chloramphenicol resistant $S$. aureus isolates, 28 and 5 of them contained gene cassettes $d h f r V, d f r A 1$ or $d f r A 12$ and cmlA6, 6 and 7 isolates were negative for any gene cassettes, 5 and 4 isolates were positive for the type $\mathrm{H}$ integron (153 bp), respectively. On the other hand, among 82 SXT susceptible and 85 chloramphenicol susceptible $S$. aureus isolates, 45 and $13 \mathrm{~S}$. aureus isolates contained gene cassettes $d h f r V$, $d f r A 1$ or $d f r A 12$ and cmlA6, respectively. The rest of susceptible isolates harbored other cassettes (Table 1).

\section{Discussion}

To the best of our knowledge, this is the first report of the presence of a class 1 integron and the resistance gene cassettes in bovine milk associated $S$. aureus isolates in China. The emergence of different resistance gene cassettes/arrays may reflect antibiotic selective pressure in our region, and provide useful antimicrobial 


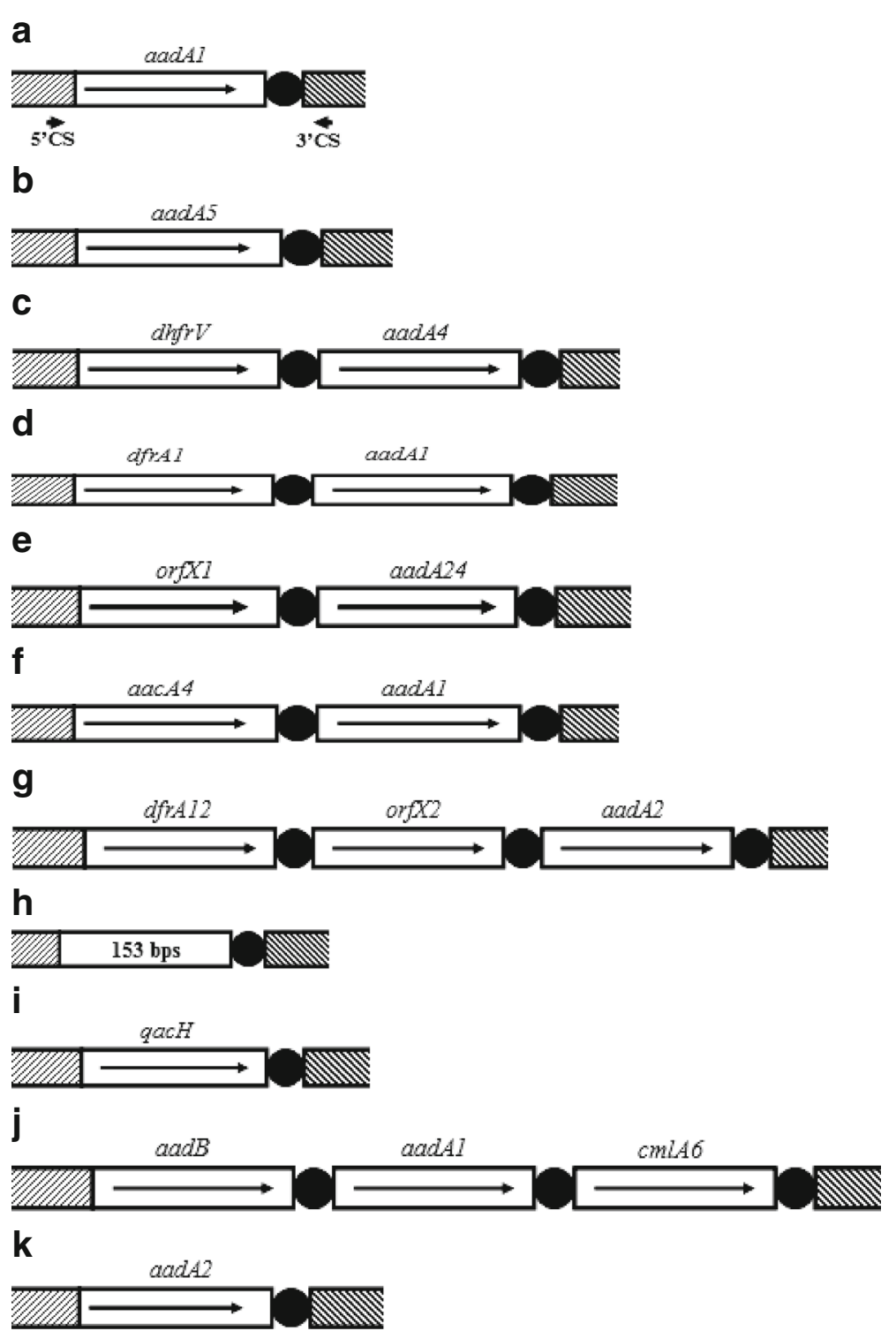

Fig. 1 Schematic representation of the variable regions identified in bovine milk associated isolates. Cassette types (a-k) are arranged as identified in Table 2. Gene cassettes are shown as boxes, with arrows for the orientation of transcription and black circles for the 59-base elements. Hatched rectangles designate 5'- and 3'- conserved segments (CSs). The 5'CS and 3'CS amplification primers are indicated by arrowheads

surveillance information for the rational and effective use of antimicrobials. Different types of class 1 integrons were characterized which carried a variety of antibiotic resistance gene cassettes/arrays. All bovine milkassociated $S$. aureus isolates were carried by class 1 integrons. However, previous studies have documented a lower proportion of class 1 integrons among $S$. aureus isolates from hospital or farm animals, such as 53\% (16/ 30) of clinical and environmental hospital-associated $S$. aureus isolates [7], 42.5\% (76/179) of nosocomial methicillin-resistant $S$. aureus strains in China [8]. The differences between our $S$. aureus isolates and others' reported ones may reflect the difference in selection pressure due to antibiotics use in our studied region. The class 1 integrons play a major role in the acquisition, expression, and dissemination of antibiotic resistance genes and may potentially have the capability to integrate nearly all the antimicrobial resistant genes such as $\beta$-lactamases, aminoglycosides, chloramphenicol, sulfonamides, macrolides, trimethoprim, fosfomycin, quinolone and quaternary ammonium compound [16] to disseminate multidrug resistance in clinical bacteria isolates. In our study, we found that aminoglycosides resistance determinants (aadA1, aadA5, aadA4, aadA24, aacA4, aadA2 and $a a d B$ ), trimethoprim resistance genes (dhfrV, dfrA1 and dfrA12) and chloramphenicol 
Table 3 Different combination of gene cassette arrays among 121 bovine milk associated S. aureus isolates

\begin{tabular}{ll}
\hline Gene cassette arrays & No. of isolates (\%) \\
\hline$H$ & $26(21.5 \%)$ \\
$D+K+A+H$ & $22(18.2 \%)$ \\
$J+G+D$ & $18(14.9 \%)$ \\
$G+H$ & $8(6.6 \%)$ \\
$D+K+H$ & $8(6.6 \%)$ \\
$D+A$ & $5(4.1 \%)$ \\
$F+C+B+A$ & $3(2.5 \%)$ \\
$G$ & $3(2.5 \%)$ \\
$E+K+H$ & $2(1.7 \%)$ \\
$G+K+H$ & $2(1.7 \%)$ \\
$G+K+I$ & $2(1.7 \%)$ \\
$D+H$ & $1(0.83 \%)$ \\
$F+C+H$ & $1(0.83 \%)$ \\
$K+A$ & $1(0.83 \%)$ \\
$G+E+H$ & $1(0.83 \%)$ \\
\hline
\end{tabular}

resistance determinants ( $\mathrm{cmlA6}$ ) were prevalent among pathogenic $S$. aureus isolated from milk of mastitic cows. Those antimicrobial-resistance genes organized into 11 different gene cassettes arrangements (Fig. 1) and 74 isolates contained different combinations of gene cassette arrays, such as 22 isolates with the combination $\mathrm{D}+\mathrm{K}+$ $\mathrm{A}+\mathrm{H}$ and 18 isolates with the combination $\mathrm{J}+\mathrm{G}+\mathrm{D}$ (Table 3). This may be due to the fact that aminoglycosides, chloramphenicol and trimethoprim were often widely used for the prevention or treatment of bovine mastitis in the past years in our region.

A BLAST search for our resistance gene cassettes in GenBank revealed high similarities were found with the published sequence in Salmonella or Escherichia coli isolates from different geographical locations or sources. This data suggests that class 1 integron/cassettes may contribute significantly to the horizontal transfer of antimicrobial resistance genes among different bacterial species from different sources or geographical locations [16]. However, the gene cassettes observed in class 1 integrons examined in our study did not account for the total resistance phenotypes observed (erythromycin, tetracyclines, clindamycin and pencillins antibiotics) among the pathogenic $S$. aureus isolates (Table 1). This suggests bovine milk associated $S$. aureus resistance to erythromycin, tetracyclines and pencillins may be not associated with integronmediated antimicrobial resistance. And this could possibly reflect the presence of other mobile DNA elements, such as plasmid and transposon, or other resistance genes that we could not detected in this study.

The occurrence of resistance gene cassettes associated aminoglycosides resistance genes including aadA1,
aadA5, aadA4, aadA24, aacA4, aadA2 and $a a d B$ were relatively high among the $S$. aureus isolates. Similarly, a large proportion was reported in the case of clinical isolates of Escherichia coli in China hospital [14] and Salmonella enterica isolates from animal and human in Iran [4]. Furthermore, extensive existence of a variety of aadA alleles among $S$. aureus isolates indicates frequent recombination events in integrons. Similar allelic diversity has also been reported in Escherichia coli [17]. Therefore, class 1 integron/cassettes mediated capture of gene cassettes conferring resistance to aminoglycosides agents may play an important role among the antibioticresistant $S$. aureus isolates obtained from bovine milk. In addition, aminoglycoside antibiotic (neomycin, kanamycin or gentamicin) alone or combined with an antibiotic from another family (pencillins, ampicillin, macrolides or tetracyclines) has been widely used in the treatment of $S$. aureus intramammary infection on the local dairy farms. The class 1 integron exhibits a number of characteristics that might have adopted to antimicrobial agents by obtaining diverse gene cassettes with resistant genes. Human activities promote the diversification and dissemination of class 1 integrons [18].

In the present study, 45 and 13 isolates had the $d h f r V$, $d f r A 1$ or $d f r A 12$ and $c m l A 6$ gene cassettes while being phenotypically susceptible to SXT and chloramphenicol, respectively. The reasons for this phenomenon may be due to the presence of the weak promoter (strong promoter Pc variant) or repressors led to gene cassette expression transcriptional inactivation $[19,20]$. The resistance gene cassette expression also can be affected by differences in the length and the sequence of $a t t C$ sites, since the $a t t C$ sites are imperfect inverted repeats that may form stemloop structures similar to $\rho$-independent transcription terminators once they have been transcribed $[19,21]$. From the clinical standpoint, those susceptible $S$. aureus isolates may be the genetic source for the evolution of resistance to clinically relevant antibiotics through mutation of regulatory sequences or integrase-mediated gene cassette rearrangements [19].

\section{Conclusions}

In summary, all 121 tested bovine milk-associated S. aureus isolates carried class 1 integrons and 103 isolates contained different gene cassettes and we have presented evidence for the first time for class 1 integron as possible antibiotic resistance determinants on Chinese dairy farms.

\section{Abbreviations}

3'CS: 3' conserved segment; 5'CS: 5' conserved segment; S. aureus: Staphylococcus aureus; SXT: Trimethoprim/sulfamethoxazole

Acknowledgments

$L P L$ and $X Z$ thank the farmers for providing milk samples. 


\section{Funding}

This study was financially supported by a grant from the National Science Foundation of China (31372282) and the China Thousand Talents Program. This work was also supported By Young Talent fund of University Association for Science and Technology in Shaanxi, China (20160236). The funders had no role in study design, data collection and analysis, decision to publish, or preparation of the manuscript.

\section{Availability of data and materials}

All the data supporting the results are included in the article.

\section{Authors' contributions}

$L P L$ and $X Z$ conceived and designed the experiments; LPL conducted the laboratory experiments; LPL and XZ performed the data analysis; $L P L$ and $X Z$ wrote the manuscript. Both authors read and approved the final manuscript.

\section{Ethics approval and consent to participate}

Milk samples were taken by farmers and no ethics approval was considered necessary.

\section{Consent for publication}

Not applicable.

\section{Competing interests}

The authors declare that they have no competing interests.

\section{Publisher's Note}

Springer Nature remains neutral with regard to jurisdictional claims in published maps and institutional affiliations.

\section{Author details}

${ }^{1}$ College of Animal Science and Technology, Northwest A\&F University, YangLing, Shaanxi, People's Republic of China. ' Life Science Research Center, Yulin University, Yulin 719000, People's Republic of China. ${ }^{3}$ Shaanxi Provincial Engineering and Technology Research Center of Cashmere Goat, Yulin University, Yulin 719000, People's Republic of China. ${ }^{4}$ Department of Animal Science, McGill University, 21,111 Lakeshore, Ste. Anne de Bellevue, Quebec H9X 3V9, Canada.

Received: 10 January 2017 Accepted: 15 February 2018

Published online: 27 February 2018

\section{References}

1. Malachowa N, DeLeo FR. Mobile genetic elements of Staphylococcus aureus. Cell Mol Life Sci. 2010;67(18):3057-71.

2. Gillings MR. Integrons: past, present, and future. Microbiol Mol Biol Rev. 2014;78(2):257-77.

3. Mazel D. Integrons: agents of bacterial evolution. Nat Rev Microbiol. 2006; 4(8):608-20

4. Firoozeh F, Zahraei-Salehi T, Shahcheraghi F. Molecular clonality and detection of class 1 integron in multidrug-resistant Salmonella enterica isolates from animal and human in Iran. Microb Drug Resist. 2014;20(6):517-24.

5. Wu K, Wang F, Sun J, Wang Q, Chen Q, Yu S, Rui Y. Class 1 integron gene cassettes in multidrug-resistant gram-negative bacteria in southern China. Int J Antimicrob Agents. 2012;40(3):264-7.

6. Nandi S, Maurer JJ, Hofacre C, Summers AO. Gram-positive bacteria are a major reservoir of class 1 antibiotic resistance integrons in poultry litter. Proc Natl Acad Sci. 2004;101(18):7118-22.

7. Xu Z, Shi L, Zhang C, Zhang L, Li X, Cao Y, Li L, Yamasaki S. Nosocomial infection caused by class 1 integron-carrying Staphylococcus aureus in a hospital in South China. Clin Microbiol Infec. 2007:13(10):980-4.

8. Xu Z, Li L, Shirtliff ME, Peters BM, Li B, Peng Y, Alam MJ, Yamasaki S, Shi L. Resistance class 1 integron in clinical methicillin-resistant Staphylococcus aureus strains in southern China, 2001-2006. Clin Microbiol Infec. 2011;17(5):714-8.

9. Xu Z, Li L, Alam MJ, Zhang L, Yamasaki S, Shi L. First confirmation of integron-bearing methicillin-resistant Staphylococcus aureus. Curr Microbiol. 2008;57(3):264-8.

10. Li L, Zhou L, Wang L, Xue H, Zhao X. Characterization of methicillin-resistant and -susceptible staphylococcal isolates from bovine milk in northwestern china. PLoS One. 2015;10(3):e0116699.
11. Clinical and Laboratory Standards Institute. Performance standards for antimicrobial disk and dilution susceptibility tests for bacteria isolated from animals: informational supplement. Wayne: CLSI document; 2004. p. M31-S1.

12. Clinical and Laboratory Standards Institute. Performance standards for antimicrobial susceptibility testing; twenty-first informational supplement. Wayne: CLSI document; 2011. p. M100-S21.

13. Li L, Feng W, Zhang Z, Xue H, Zhao X. Macrolide-lincosamide-streptogramin resistance phenotypes and genotypes of coagulase-positive Staphylococcus aureus and coagulase-negative staphylococcal isolates from bovine mastitis. BMC Vet Res. 2015;11:168.

14. Su J, Shi L, Yang L, Xiao Z, Li X, Yamasaki S. Analysis of integrons in clinical isolates of Escherichia coli in China during the last six years. FEMS Microbiol Lett. 2006;254(1):75-80.

15. Levesque $C$, Piche L, Larose $C$, Roy PH. PCR mapping of integrons reveals several novel combinations of resistance genes. Antimicrob Agents Chemother. 1995;39(1):185-91.

16. Partridge SR, Tsafnat G, Coiera E, Iredell JR. Gene cassettes and cassette arrays in mobile resistance integrons. FEMS Microbiol Rev. 2009;33(4):757-84.

17. Blahna MT, Zalewski CA, Reuer J, Kahlmeter G, Foxman B, Marrs CF. The role of horizontal gene transfer in the spread of trimethoprim-sulfamethoxazole resistance among uropathogenic Escherichia coli in Europe and Canada. J Antimicrob Chemother. 2006:57(4):666-72.

18. Gillings MR. Class 1 integrons as invasive species. Curr Opin Microbiol. 2017;38:10-5.

19. Rowe-Magnus DA, Mazel D. The role of integrons in antibiotic resistance gene capture. Int J Med Microbiol. 2002;292(2):115-25.

20. Rowe-Magnus DA, Mazel D. Resistance gene capture. Curr Opin Microbiol. 1999;2(5):483-8.

21. Martinez-Freijo P, Fluit AC, Schmitz FJ, Grek VS, Verhoef J, Jones ME. Class I integrons in gram-negative isolates from different European hospitals and association with decreased susceptibility to multiple antibiotic compounds. J Antimicrob Chemother. 1998;42(6):689-96.

\section{Submit your next manuscript to BioMed Central and we will help you at every step:}

- We accept pre-submission inquiries

- Our selector tool helps you to find the most relevant journal

- We provide round the clock customer support

- Convenient online submission

- Thorough peer review

- Inclusion in PubMed and all major indexing services

- Maximum visibility for your research

Submit your manuscript at www.biomedcentral.com/submit
Biomed Central 